\title{
Physicochemical Characteristics, in Vitro Fermentation Indicators, Gas Production Kinetics, and Degradability of Solid Herbal Waste as Alternative Feed Source for Ruminants
}

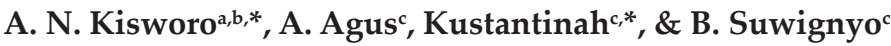 \\ ${ }^{a}$ Sekolah Tinggi Penyuluhan Pertanian (STPP) Bogor \\ Jalan Aria Surialaga, Pasir Jaya, Bogor Barat, Kota Bogor 16119, Indonesia \\ bPostgraduate Program, Faculty of Animal Science, Gadjah Mada University \\ ${ }^{c}$ Department of Nutrition and Animal Feed, Faculty of Animal Science, Gadjah Mada University \\ Jalan Fauna No. 3, Bulaksumur, Kabupaten Sleman, Daerah Istimewa Yogyakarta 55281, Indonesia \\ (Received 17-02-2017; Reviewed 05-04-2017; Accepted 16-05-2017)
}

\begin{abstract}
The aims of this research were to study the nutrient and secondary metabolite contents of solid herbal wastes (SHW) that were preserved by freeze drying, sun drying and silage, as well as to analyze their effects on in vitro fermentation indicators i.e., gas production kinetics and degradability of solid herbal waste. Physical and chemical properties on three forms of SHW (sun dry, freeze dry, and silage) were characterized and then an in vitro gas production experiment was performed to determine the kinetics of gas production, methane production, $\mathrm{NH}_{3}$, microbial protein, and $\mathrm{SHW}$ degradability. Polyethylene glycol (PEG) was added to the three treatments to determine the biological activity of tannins. Results showed that all three preparations of SHW still contained high nutrient and plant secondary metabolite contents. Gas production, methane, $\mathrm{NH}_{3^{\prime}}$ microbial protein, in vitro degradability of dry matter (IVDMD) and organic matter (IVDOM) of SHW silage were lower $(\mathbf{P}<0.05)$ compared to sun dry and freeze dry. These results were apparently due to the high content of secondary metabolites especially tannin. It can be concluded that solid herbal wastes (SHW) can be used as an alternative feed ingredients for ruminants with attention to the content of secondary metabolites that can affect the process of fermentation and digestibility in the rumen.
\end{abstract}

Keywords: solid herbal waste, plant secondary metabolites, antimicrobial effect, in vitro rumen fermentation

\begin{abstract}
ABSTRAK
Penelitian ini bertujuan untuk mengevaluasi efek limbah padat jamu (LPJ) yang mengandung berbagai metabolit sekunder tanaman pada kinetika produksi gas, indikator fermentasi, dan kecernaan dalam rumen pada kondisi in vitro. Pada tahap pertama penelitian dilakukan analisis fisik dan kimia pada tiga sediaan LPJ (kering matahari, freeze dry, dan silase), selanjutnya dilakukan percobaan in vitro produksi gas untuk mengetahui kinetika produksi gas, produksi metan, $\mathrm{NH}_{3^{\prime}}$ protein mikrobia, dan tingkat degradasi LPJ secara in vitro. Polyethylene glycol (PEG) ditambahkan pada ketiga perlakuan untuk mempelajari aktivitas biologis tanin. Hasil penelitian menunjukkan ketiga sediaan LPJ masih mengandung nutrien dan metabolit sekunder tanaman yang relatif tinggi. Produksi gas, metan, $\mathrm{NH}_{3}$, protein mikrob, dan degradasi in vitro bahan kering dan bahan organik silase LPJ lebih rendah $(\mathbf{P}<0.05)$ dibandingkan LPJ kering matahari dan freeze dry yang diduga disebabkan oleh kandungan metabolit sekunder, terutama tanin yang tinggi. Melihat potensi kandungan nutriennya, dapat disimpulkan bahwa limbah padat jamu (LPJ) dapat digunakan sebagai alternatif bahan pakan pengganti serat dengan perhatian pada kandungan metabolit sekunder yang dapat mempengaruhi proses fermentasi dan kecernaan di dalam rumen.
\end{abstract}

Kata kunci: limbah padat jamu, metabolit sekunder tanaman, efek antimikrob, fermentasi rumen in vitro

${ }^{*}$ Corresponding author:

E-mail: arifnindyo@yahoo.co.id; kustantinah@ugm.ac.id 


\section{INTRODUCTION}

Solid herbal waste (SHW) is the dregs or the rest of various herbs part like leaf, stem, bark, fruits, seeds, and roots or rhizomes from extraction process that are not used anymore. These parts may potentially be used as animal feed supplements because they still contain nutrients such as carbohydrates, protein, and crude fiber (Kisworo et al., 2016). Feed development from medicinal waste is expected to be an alternative solution to fulfill fibrous feed materials for ruminant livestock, especially around the area where the herbal industry is located, because the industry generates high amounts of herbs waste, such as PT. Sido Muncul which produces 17 tons of solid herbal waste per day (Amir \& Lestari, 2013). This waste may pollute the environment if it is not properly handled.

Further, solid herbal waste also contains a variety of plant secondary metabolites and lignin (Kisworo et al., 2016). Kamra et al. (2012) defines the plant secondary metabolites as chemical substances which are synthesized by plants, but not essential in the primary process of biochemical growth and reproduction of plants, this plant bioactive has antimicrobial properties that aims to protect the plant from foreign particles attack including microbial pathogens. When ruminant consumes solid herbal waste, the antimicrobial characteristics of this herbal waste may certainly affect rumen microbial populations. This in turn might also affect the characteristics of rumen fermentation such as ammonia concentration, VFA, protozoa, microbial protein, and methane. For this reason, the content of plant secondary metabolites in solid herbal waste must be known such as tannin. According to Patra et al. (2012), tannins are polyphenolic polymers of relatively high molecular weight with the capacity to form complexes mainly with protein due to the presence of large number of phenolic hydroxyl groups. Tannin is ubiquitously distributed in forage trees, shrubs, legumes, cereals, and grains. Intake of forages containing high concentration of tannin in animals may show adverse effects on feed intake, nutrient utilization, and animal performance. However, tannins may modulate rumen fermentation favourably, such as decreased protein degradation of high quality feed stuff in the rumen and increase its availability post ruminally (Jayanegara \& Sofyan, 2008), inhibition of methanogenesis (Patra \& Saxena, 2010), and increased microbial protein synthesis (Al-Dobaib, 2009). An easy and simple method to analyze the biological activity of tannin is by adding polyethylene glycol (PEG) into the in vitro fermentation to inactivate tannins (Jayanegara \& Sofyan, 2008). Polyethylene glycol (PEG) is a chemical compound that has a high affinity for tannins causing tannins bind PEG and become unable to react. The increased gas production after the addition of PEG is a measure of the tannin activity in plants (Jayanegara et al., 2009). In addition to tannins, other secondary metabolites will also affect the digestive processes in the rumen and therefore must be analyzed as well. Wink (2015) indicated that the herbs extracts contain not only one kind of secondary metabolites, but also dozens or even hundreds of secondary metabolites of some structural groups. Therefore, the effect of the herb could be the interaction among various secondary metabolites that can not be detected if only one kind of metabolites was evaluated.

Fresh solid herbal waste contains high moisture and requires preservation to prevent deterioration and to maintain nutritional quality. Preservation methods by ensilage and air or sun drying are simple and easy to be applied to SHW. Therefore, the objective of this experiment was to study the effect of different preservation techniques on nutrient and secondary metabolite contents of solid herbal waste and to analyze their effects on in vitro fermetation parameters, gas production kinetics, fermentation, and digestibility in the rumen in vitro.

\section{MATERIALS AND METHODS}

Samples were taken from the solid herbal waste disposal sites of PT. Deltomed Laboratories. The samples were the leftover of herbal medicine processing into product of Antangin ${ }^{\circledR}$ that consisted of residues of roots or rhizomes, stems, and leaves of the mint plant (Mentha piperita), sembung (Blumea balsamivera), and ginger (Zingiber oficinale). The equipments used were a set of tools for proximate analysis according to AOAC (2005). Rumen fluid for in vitro gas test was obtained from two Peranakan Ongole cows given a ration of king grass and concentrate with a ratio of 70:30 (dry matter basis), with a minimum crude protein and total digestible nutrient (TDN) of $12 \%$ and $68 \%$, respectively. Concentrate composition consisted of wheat bran, soybean meal, molasses, corn bran, salt, and minerals. Rations were given twice in a day with the total amount of provision was approximately $3 \%$ of live weight.

\section{Sampling and Chemical Composition Analysis of Solid Herbal Waste}

Fresh sample of solid herbal waste was taken from PT Deltomed Laboratories waste tank in five points randomly with each weighing about $1.000 \mathrm{~g}$. The samples were kept in a box and then taken to the laboratory for analysis. Fresh sample of solid herbal waste was prepared in three preparations with three replications each, namely: 1) freeze dried at a temperature of $-40^{\circ} \mathrm{C}, 2$ ) made into silage with the addition of $10 \%$ molasses as a source of water soluble carbohydrate (WSC), ensiled for $28 \mathrm{~d}$, then dried in the freeze dryer, and 3) sun dried samples obtained from sun drying at 7.30 AM - 4 PM for 3-4 d until constant weight was obtained. After drying, the samples were milled using Willey mill to pass through a $1 \mathrm{~mm}$ sieve. The samples were then stored in plastic clip at $-5^{\circ} \mathrm{C}$ in the refrigerator for the next stage of analysis. The solid herbal waste content of dry matter (DM), organic matter (BO), crude protein (CP; $\mathrm{N} x 6.25)$, and ether extract (EE) was then analyzed by proximate analysis according to AOAC (2005).

The nitrogen free extract (NFE) was obtained by the following formula: NFE $=[100-($ Ash + CF + EE $+\mathrm{CP})] \%$. Total digestible nutrien (TDN) of sun dried and freeze dried SHW was estimated according to Hartadi et al. (2005) with the following formula: TDN= 
$-26.685+1.334(\mathrm{CF})+6.598(\mathrm{EE})+1.423(\mathrm{NFE})+0.967(\mathrm{CP})$ $-0.002(\mathrm{CF})^{2}-0.670(\mathrm{EE})^{2}-0.024(\mathrm{CF})(\mathrm{NFE})-0.065(\mathrm{EE})$ $(\mathrm{NFE})-0.146(\mathrm{EE})(\mathrm{CP})+0.039(\mathrm{EE}) 2(\mathrm{CP})$. TDN for SHW silage was estimated with the following formula: TDN= $-17.950-1.285(\mathrm{CF})+15.704(\mathrm{EE})+1.009(\mathrm{NFE})+2.371(\mathrm{CP})$ $+0.017(\mathrm{CF})^{2}-1.023(\mathrm{EE})^{2}+0.012(\mathrm{CF})(\mathrm{NFE})-0.096(\mathrm{EE})$ $(\mathrm{NFE})-0.550(\mathrm{EE})(\mathrm{CP})+0.051(\mathrm{EE})^{2}(\mathrm{CP})$.

Freeze dried, silage, and sun dried samples of solid herbal were analyzed in duplicate for the contents of total phenols, flavonoids, tannins, saponins, alkaloids, and essential oils. Saponins and total phenols were analyzed using the procedures of Stahl (1985) and Chanwitheesuk et al. (2005) respectively, and expressed as Quillaja bark and Gallic acid equivalents. Flavonoids were analyzed according to Indonesian Herbal Pharmacopoeia (Ministry of Health, 2008) using a UV-Vis spectrophotometer Hitachi U-2900 with Rutin as a standard. Total tannin content was analyzed by subtracting the amount of polyvinylpolypyrrolidone that binds with tannin and total phenols, and expressed as tannic acid equivalents (Makkar et al., 1993). Alkaloid content was measured using a spectrophotometer at a wavelength of $420 \mathrm{~nm}$ with Quinine as a standard. Essential oils was measured using a maceration method according to Materia Medica Indonesia (Ministry of Health, 1995).

\section{Analysis of Gas Production Kinetics, Fermentation Parameters, and in Vitro Digestibility}

The in vitro incubation consisted of 7 treatments with 6 replications by following a completely randomized design. The treatments were: 1) Standard= pangola grass, 2) $\mathrm{SDSHW}=$ sun dried solid herbal waste, 3) SDSHW + PEG (200 mg) 4) FDSHW = freeze dried solid herbal waste, 5) FDSHW + PEG (200 mg), 6) SilSHW= silage of solid herbal waste, and 7) SilSHW + PEG (200 $\mathrm{mg}$ ). Buffer solution was created shortly before the experiment and placed in the air bath of $38^{\circ} \mathrm{C}$, while $\mathrm{CO}_{2}$ gas flowed. The buffer was made from distilled water, micromineral, a buffer solution, a macromineral solution, and resazurin that were mixed and warmed to $39^{\circ} \mathrm{C}$ then added the reducing solution as described by Menke \& Steingass (1988). An amount of $200 \mathrm{mg}$ of pangola grass, sun dried, freeze dried, and silage of solid herbal waste was inserted into the syringe, followed by the addition of $30 \mathrm{~mL}$ of medium consisting of $10 \mathrm{~mL}$ of rumen fluid and $20 \mathrm{~mL}$ of buffer, and then the syringe piston was mounted. $200 \mathrm{mg}$ PEG was added to the other three at a temperature of $39^{\circ} \mathrm{C}$ for $72 \mathrm{~h}$ using the gas production technique by Menke et al. (1979). Gas production was recorded after incubation of 1, 2, 4, $6,8,12,24,36,48$, and $72 \mathrm{~h}$. At the end of incubation, gas sample was taken with a plastic syringe of $10 \mathrm{~mL}$ for methane analysis, and the residual gas was released. Methane was measured using gas chromatography.

Microbial protein of rumen fluid was measured using a modification of the gradual centrifuge principle by Makkar et al. (1982). The rumen fluid subsample was filtered using two layers of linnen cloth. A total of $5 \mathrm{mLl}$ of fluid was then centrifuged at 3,000 $\mathrm{g}$ for $15 \mathrm{~min}$ to separate feed protein components and rumen microbes, the supernatant was taken in Eppendorf tube and centrifuged again at $10,000 \mathrm{~g}$ for $15 \mathrm{~min}$. The precipitate was then mixed with $15 \mathrm{~mL}$ of $\mathrm{NaOH}$ and heated in boiling water in waterbath for $10 \mathrm{~min}$, homogenized with vortex and then analyzed using Lowry method by spectrophotometry (Plumer, 1987). Ammonia concentration was measured using spectrophotometry (Broderick \& Kang, 1980). The dry matter and residual samples after $72 \mathrm{~h}$ incubation were used to estimate dry matter degradability (DMD) and organic matter degradability (OMD) of feed samples, and calculated according Blummel et al. (1997).

\section{RESULTS}

Preservation of fresh solid herbal waste (SHW) to sun dry, freeze dry, and silage led to changes in odor, texture, $\mathrm{pH}$, and water content, while the color was relatively unchanged (Table 1 ). The texture of sun dry (SDSHW) and freeze dry solid herbal waste (FDSHW) became dry, rough, and brittle, whereas in the form of silage (SilSHW) became more tender and moist. The $\mathrm{pH}$ of SDSHW and FDSHW tended to be alkaline or neutral, as in the fresh state, while SilSHW pH tended to be low

Table 1. Solid herbal waste (SHW) characteristics preserved by sun drying, freeze drying and ensilage

\begin{tabular}{lcccc}
\hline \multirow{2}{*}{ Variables } & \multicolumn{4}{c}{ Preparations forms } \\
\cline { 2 - 5 } & Fresh SHW & SDSHW & FDSHW & SilSHW \\
\hline Odor & & & + & + \\
- Typical herbs & ++ & ++ & + & - \\
- Bitter herbs & +++ & ++ & - & + \\
- Sweet & - & - & Brown-Dark brown & Light brown-Dark brown \\
- Acid & - & - & & ++ \\
Color & Greenish brown-Dark & Light brown-Dark brown & Dry, coarse & Soft, moist \\
& brown & Dry, coarse & $7.26 \pm 0.47$ & $3.43 \pm 0.03$ \\
Texture & Limp, coarse, wet & $6.20 \pm 0.50$ & 10.8 & 63.7 \\
Water content $(\%)$ & $6.82 \pm 0,16$ & 9.5 & & \\
\hline
\end{tabular}

Note: + = slight odor, ++ = moderate odor, +++ = Sharp odor, - = odorless, Fresh SHW= Fresh Solid Waste, SDSHW= Sun Dried Solid Herbal Waste, FDSHW= Freeze Dried Solid Herbal Waste, SilSHW= Silage of Solid Herbal Waste, fermented in 28 days. 
with an average of 3.73. The study showed no differences in DM, CP, CF, ash, NFE, and TDN between SDSHW and FDSHW, whereas SilSHW contained lower DM and CF, and higher NFE and TDN compared to SDSHW and FDSHW (Table 2). The three forms of SHW contained total phenols, flavonoids, tannins, saponins, alkaloids, and essential oils at a different concentrations. In general, the secondary metabolite concentrations from the highest to the lowest were SilSHW > FDSHW > SDSHW. Total phenols were the highest secondary metabolites found in all three forms of SHW, followed by tannins, saponins, alkaloids, flavonoids, and essential oils.

Gas production of the three forms of SHW was lower than standard pangola grass $(\mathrm{P}<0.01$; Table 3 ) as confirmed by the profile of gas production kinetics (Figure 1). Addition of PEG did not improve gas production of SDSHW and FDSHW, but significantly $(\mathrm{P}<0.01)$ increased gas production of SilSHW (Table 4). The highest increase in gas production was occurred in the first 8-12 $\mathrm{h}$ and then began to fall after the first $12 \mathrm{~h}$, and very low after 48 to $72 \mathrm{~h}$. No difference was found between SDSHW and FDSHW gas productions, while SilSHW gas production was significantly lower $(\mathrm{P}<0.05)$ compared to SDSHW and FDSHW $(\mathrm{P}<0.05)$. The maximum gas production $(a+b)$ of SDSHW was almost the same with FDSHW, while the maximum gas production of SilSHW was significantly lower $(\mathrm{P}<0.05)$. Gas production rate (c fraction) of SDSHW was lower than FDSHW and SilSHW $(\mathrm{P}<0.05)$, while the $\mathrm{c}$ fraction between FDSHW and SilSHW was similar. Addition of PEG on SDSHW and FDSHW did not alter the maximum gas production.
The percentage of methane generated by solid herbal waste was significantly lower $(\mathrm{P}<0.01)$ compared to pangola grass. The lowest percentage of methane pro-

Table 2. Chemical and secondary metabolite compositions of solid herbal waste (SHW) and pangola grass (Digitaria decumbens)

\begin{tabular}{lrrrc}
\hline Variables & SDSHW & FDSHW & SilSHW & $\begin{array}{c}\text { Pangola } \\
\text { grass }\end{array}$ \\
\hline $\mathrm{DM}(\%)$ & 89.20 & 90.48 & 36.31 & 18.00 \\
$\mathrm{CP}(\%)^{\mathrm{a}}$ & 10.46 & 10.74 & 10.98 & 11.00 \\
$\mathrm{CF}(\%)^{\mathrm{a}}$ & 23.63 & 23.05 & 20.36 & 31.90 \\
$\mathrm{EE} \mathrm{( \% )})^{\mathrm{a}}$ & 1.64 & 2.26 & 2.17 & 3.30 \\
Ash (\%) & 5.02 & 4.91 & 5.10 & 11.50 \\
NFE (\%) & 59.25 & 59.04 & 61.40 & 42.30 \\
TDN (\%) & 66.82 & 67.49 & 71.91 & 58.45 \\
Total phenol & 11.50 & 11.53 & 12.96 & - \\
$(\%)$ & & & & \\
Tannin (\%) & 4.71 & 4.97 & 6.93 & - \\
Saponin (\%) & 3.28 & 5.03 & 6.25 & - \\
Alkaloid (\%) & 3.44 & 3.03 & 5.32 & - \\
Flavonoid & 1.86 & 1.86 & 3.20 & - \\
$(\%)$ & & & & - \\
EO (\%) & 0.21 & - & - & - \\
\hline
\end{tabular}

Note: $\mathrm{DM}=$ dry matter, $\mathrm{CP}=$ crude protein, $\mathrm{CF}=$ crude fiber, $\mathrm{EE}=$ ether extract, $\mathrm{NFE}=$ nitrogen free extract, $\mathrm{TDN}=$ total digestible nutrients, $\mathrm{EO}=$ essential oil, $\mathrm{a}=$ in $100 \% \mathrm{DM}, \mathrm{b}=$ Calculated according Hartadi et al. (2005), SDSHW= sun dried solid herbal waste, FDSHW = freeze dried solid herbal waste, SilSHW= silage of solid herbal waste, fermented in 28 days.

Table 3. Gas production, methane, ammonia, and microbial protein of solid herbal waste samples in different preparation without PEG additions

\begin{tabular}{lcccc}
\hline Variables & Pangola grass & SDSHW & FDSHW & SilSHW \\
\hline Gas production $(\mathrm{mL} / 200 \mathrm{mg})$ & $55.57 \pm 2.69^{\mathrm{a}}$ & $39.63 \pm 1.17^{\mathrm{b}}$ & $39.18 \pm 1.09^{\mathrm{b}}$ & $34.40 \pm 3.61^{\mathrm{c}}$ \\
Methane (\%) & $13.12 \pm 0.04^{\mathrm{a}}$ & $10.31 \pm 0.42^{\mathrm{bc}}$ & $11.07 \pm 0.48^{\mathrm{b}}$ & $8.95 \pm 1.46^{\mathrm{c}}$ \\
$\mathrm{NH}_{3}(\mathrm{mg} / 100 \mathrm{~mL})$ & $29.21 \pm 1.07^{\mathrm{a}}$ & $20.94 \pm 0.90^{\mathrm{b}}$ & $21.62 \pm 2.08^{\mathrm{b}}$ & $21.70 \pm 0.10^{\mathrm{b}}$ \\
Microbial protein $(\mathrm{mg} / 100 \mathrm{~mL})$ & $9.67 \pm 0.11^{\mathrm{a}}$ & $14.43 \pm 1.80^{\mathrm{b}}$ & $14.70 \pm 0.65^{\mathrm{b}}$ & $10.4 \pm 1.39^{\mathrm{a}}$ \\
\hline
\end{tabular}

Note: Mean in the same rows with different superscripts differ significantly $(\mathrm{P}<0.01)$. SDSHW= sun dried solid herbal waste, FDSHW= freeze dried solid herbal waste, SilSHW= silage of solid herbal waste, fermented in 28 days.

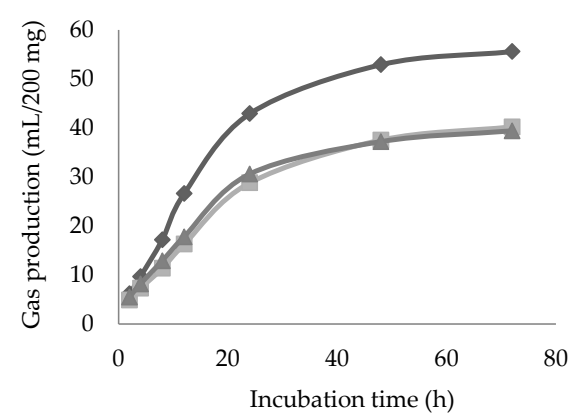

A

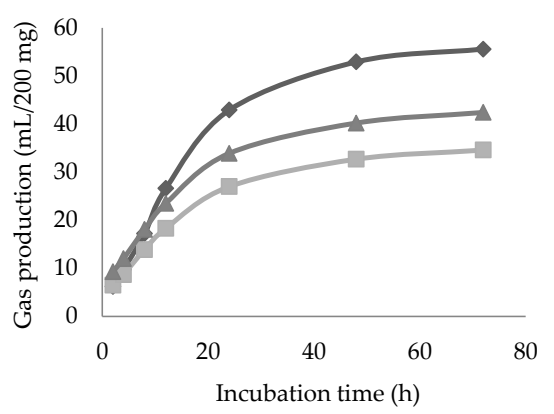

B

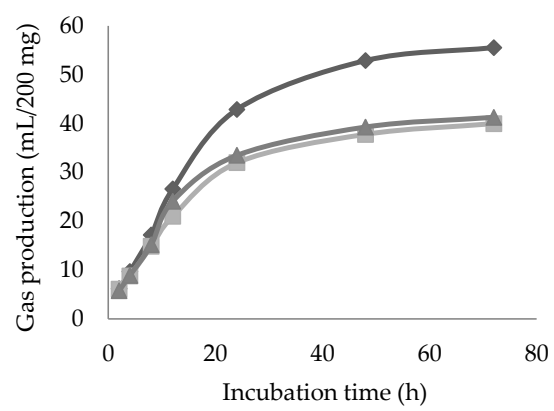

C

Figure 1. Cumulatives gas production of Pangola grass (- $\downarrow-)$ and solid herbal waste in three different preparation (sun dry [A], silage $[\mathrm{B}]$, freeze dry [C]), without (-m-) and with the addition of PEG (- $\mathbf{\Delta}-)$. 
duction was observed in SilSHW. Ammonia production by SDSHW, FDSHW, and SilSHW did not differ among treatments, but significantly lower than pangola grass $(\mathrm{P}<0.05$; Table 5). Microbial protein production from SDSHW was similar with FDSHW, while the microbial protein of SilSHW was significantly lower $(\mathrm{P}<0.05)$ compared to SDSHW and FDSHW. Organic matter digestibilities (OMD) of all form of SHW without PEG addition were not significantly different, although OMD of SilSHW tended to be lower. The OMD of SHW with and without PEG addition was significantly different $(\mathrm{P}<0.01)$, where with PEG addition the OMD of SDSHW was the highest as compared to FDSHW and SilSHW.

\section{DISCUSSION}

\section{Physical and Chemical Characteristics of Solid Herbal Waste}

Typical odor of herbs and bitter odor in the dried solid waste and silage was greatly reduced compared to fresh solid herbal waste, and silage produced sweet aroma and slightly sour. In the drying process, reduced water content inhibits plant respirations and fermentations by microbial activity, thereby inhibiting the breakdown of solid waste and preserving herbs; this method of drying resembles the process of hay making where the optimal moisture content is between $15 \%$ 18\% (Utomo, 2016; Kellem \& Church, 2010). The water content of SDSHW and FDSHW were close to $10 \%$; it is low enough to prevent nutritional content from being damaged when stored in the long term. With regard to silage, good quality silage must meet the following $\mathrm{pH}<3.9-4.2$, however, pre-wilted grass silage can be preserved at higher $\mathrm{pH}(4.5-4.7)$ in order to preserve the nutrient content (Manyawu et al., 2016). The water content of solid herbal waste silage in this study was

Table 4. Total gas production kinetics and methane of solid herbal waste in different preparation without and with PEG additions

\begin{tabular}{ccccc}
\hline \multirow{2}{*}{ Variables } & \multicolumn{4}{c}{ Treatments } \\
\cline { 2 - 5 } & PEG & SDSHW & FDSHW & SilSHW \\
\hline $\mathrm{a}+\mathrm{b}(\mathrm{mL})$ & - & $41.8 \pm 1.36^{\mathrm{a} 1}$ & $39.7 \pm 1.18^{\mathrm{a} 1}$ & $35.2 \pm 0.11^{\mathrm{b} 1}$ \\
& + & $40.2 \pm 0.91^{\mathrm{a} 1}$ & $39.7 \pm 2.49^{\mathrm{a} 1}$ & $43.7 \pm 0.96^{\mathrm{a} 2}$ \\
$\mathrm{c}(\mathrm{mL} / \mathrm{h})$ & - & $0.044 \pm 0.003^{\mathrm{a} 1}$ & $0.059 \pm 0.001^{\mathrm{b} 1}$ & $0.052 \pm 0.003^{\mathrm{b} 1}$ \\
& + & $0.051 \pm 0.002^{\mathrm{a} 1}$ & $0.064 \pm 0.005^{\mathrm{b} 1}$ & $0.057 \pm 0.000^{\mathrm{ab} 1}$ \\
$\mathrm{Gas}(\mathrm{mL})$ & - & $39.63 \pm 1.17^{\mathrm{a} 1}$ & $39.18 \pm 1.09^{\mathrm{a} 1}$ & $34.40 \pm 3.61^{\mathrm{b} 1}$ \\
& + & $38.83 \pm 1.61^{\mathrm{a} 1}$ & $39.40 \pm 2.71^{\mathrm{a} 1}$ & $43.14 \pm 1.89^{\mathrm{b} 2}$ \\
$\mathrm{CH}_{4}(\%)$ & - & $10.31 \pm 0.417^{\mathrm{ab} 1}$ & $11.07 \pm 0.481^{\mathrm{a} 1}$ & $8.95 \pm 1.457^{\mathrm{b} 1}$ \\
& + & $10.83 \pm 0.134^{\mathrm{a} 1}$ & $9.52 \pm 0.509^{\mathrm{a} 1}$ & $9.91 \pm 2.236^{\mathrm{a} 1}$ \\
\hline
\end{tabular}

Note: $\mathrm{PEG}=$ Polyethilene glicol, SDSHW= Sun Dried Solid Herbal Waste, FDSHW $=$ Freeze Dried Solid Herbal Waste, SilSHW= Silage of Solid Herbal Waste, $(a+b)=$ theoretical maximum of gas production; $\mathrm{c}=$ gas production rate; ${ }^{\mathrm{ab}}$ Means in the same row with different superscripts differ significantly $(\mathrm{P}<0.05),{ }^{12}$ Means in the same columm with different superscripts differ very significantly $(\mathrm{P}<0.01)$.
$63.69 \%$, this causes the wet physical form of silage. When compared to the normal water content of grass silage, SilSHW moisture content was still in the normal range. The water content of SilSHW comes from herbs, molasses, and water formed due to respiration during ensilage. According to Kellem \& Church (2010), grass silage moisture content should be between $50 \%-72 \%$, further explained that at the beginning of ensilage, aerobic fermentation converts the organic (carbon-containing) materials into carbon dioxide, water, whereas anaerobic fermentation produces organic acids (butyric, acetic, and lactic acid). Preserving SHW by drying and ensiling is able to inhibit the growth of fungi on the feed thus preventing from damage. Almost no mould was found on SDSHW and FDSHW; mould only grew slightly on the surface of the silage where it was attributable to the presence of air at the beginning of silage making.

Crude protein (CP) content of SHW was relatively similar with pangola grass that used as the standard in this study, but higher than the other fibrous feed materials such as corn stover $(8.57 \%$ CP) (Utomo et al., 2011) and napier grass at 60 days of age $(6.51 \% \mathrm{CP})$ (Nurjana et al., 2016). The CF ranges of the three forms of SHW were lower than the aerial parts of corn stover $(27.92 \%)$ (Utomo et al., 2011) and napier gass (29.51\%) (Nurjana et al., 2016). Nitrogen free extract (NFE) of SHW was higher than pangola grass, indicating that SHW contained a higher soluble carbohydrate. The relatively high contents of $\mathrm{CP}$ and NFE and a relatively lower content of CF than other fiber sources of animal feed ingredients indicate the potency of SHW as alternative feed ingredient for ruminants. The results of the analysis of CF and NFE of SHW in this study differed from a previous study conducted by Kisworo et al. (2016) that was suspected due to a variation in sampling.

The secondary metabolite content of FDSHW tends to be higher than SDSHW and this result was similar

Table 5. Ammonia concentration, microbial protein, in vitro dry matter degradability, and organic matter degradatibility of solid herbal waste in different preparation without and with PEG additions

\begin{tabular}{lcccc}
\hline \multirow{2}{*}{ Variables } & \multicolumn{4}{c}{ Treatments } \\
\cline { 2 - 5 } & PEG & SDSHW & FDSHW & SilSHW \\
\hline $\mathrm{NH}_{3}$ & - & $20.94 \pm 0.90^{\mathrm{a} 1}$ & $21.62 \pm 2.08^{\mathrm{a} 1}$ & $21.70 \pm 0.10^{\mathrm{a} 1}$ \\
$(\mathrm{mg} / 100 \mathrm{~mL})$ & + & $14.72 \pm 1.18^{\mathrm{b} 2}$ & $14.95 \pm 1.33^{\mathrm{b} 2}$ & $13.64 \pm 1.76^{\mathrm{a} 2}$ \\
Microbial & - & $14.43 \pm 1.80^{\mathrm{b} 1}$ & $14.70 \pm 0.65^{\mathrm{b} 1}$ & $10.40 \pm 1.39^{\mathrm{a} 1}$ \\
protein & + & $14.20 \pm 3.83^{\mathrm{a} 1}$ & $16.60 \pm 0.67^{\mathrm{ab} 1}$ & $17.89 \pm 2.03^{\mathrm{b} 2}$ \\
(mg/100mL) & & & & \\
IVDMD $(\%)$ & - & $41.97 \pm 2.53^{\mathrm{b} 1}$ & $45.01 \pm 0.01^{\mathrm{b} 1}$ & $36.35 \pm 3.12^{\mathrm{a} 1}$ \\
& + & $40.09 \pm 3.52^{\mathrm{b} 1}$ & $32.36 \pm 0.42^{\mathrm{a} 2}$ & $37.32 \pm 3.58^{\mathrm{b} 1}$ \\
IVOMD $(\%)$ & - & $52.97 \pm 2.22^{\mathrm{b} 1}$ & $52.72 \pm 2.94^{\mathrm{b} 1}$ & $47.60 \pm 3.60^{\mathrm{a} 1}$ \\
& + & $60.50 \pm 5.19^{\mathrm{c} 2}$ & $43.83 \pm 2.97^{\mathrm{a} 2}$ & $51.03 \pm 3.17^{\mathrm{b} 1}$ \\
\hline
\end{tabular}

Note: $\mathrm{PEG}=$ Polyethilene glicol, $\mathrm{SDSHW}=$ Sun Dried Solid Herbal Waste, FDSHW= Freeze Dried Solid Herbal Waste, SilSHW= Silage of Solid Herbal Waste, IVDMD= in vitro dry matter digestibility, IVOMD= in vitro organic matter digestibility; abMeans in the same row with different superscripts differ significantly $(\mathrm{P}<0.05),{ }^{12} \mathrm{Means}$ in the same columm with different superscripts differ very significantly $(\mathrm{P}<0.01)$. 
to the results of study conducted by Oni et al. (2015) on various vegetable leaves that freeze dried vegetables were noted to record high value of the anti-nutritional components (tannin, saponin, and oxalate) than those were oven dried and sun dried. The cause of high levels of secondary metabolites in SilSHW was not known for certain. However, it is assumed that one of the reasons is due to the addition of phenolic compounds from molasses by $10 \%$ as a soluble carbohydrate source to accelerate the decline in $\mathrm{pH}$ during ensilage. According to Valli et al. (2012), molasses containing phenolic compounds (381.62 $\pm 6.82 \mu \mathrm{g} / \mathrm{g}$ molasses) have high antioxidant effects. Some research results suggest that fermentation process can decrease or increase the content of phenols, flavonoids, and tannins. The increases in phenols and tannins in fermentation products were found in researches conducted by Osman (2011) and Nazarni et al. (2016), while Liu et al. (2017) found that fermetation of rice bran by lactic acid bacteria and complex enzyme hydrolysis, increased total phenolics, total flavonoids, and antioxidant activity. Dordevic' et al. (2010) reported that lactic acid fermentation increased the phenolic content and antioxidant activity in some cereals, but the efficiency was very low. According to Martins et al. (2011), during fermentation, the complex polyphenols are hydrolyzed into simpler and more biologically active compounds, whereas $\beta$-glucosidase might cleavage inter-sugar relations and release corresponding hydrolyzed glycosides liberate phenolic aglycon moieties.

The decrease in phenolic compounds during fermentation are occurred in some researches. Researches conducted by Rodriguez et al. (2009) and Othman et al. (2009) show that Lactic acid bacteria are able to degrade some food phenolic compounds. The presence of lactic acid bacteria in fermentation contributes to the simple phenolic conversion and the depolymerization of high molecular weight phenolic compounds (Othman et al., 2009). Research conducted by Landete et al. (2008) shows that phenolic acids of Spanish-style green olives may inhibit lactic acid bacteria, but Lactobacillus plantarum may also degrade some phenolic compounds by inducible enzymes.

\section{Effects of Solid Herbal Waste on Fermentation Parameters and in Vitro Digestibility}

Gas production of SHW was relatively lower compared to standard. The gas formed during the fermentation process is the result of the decomposition of carbohydrate polymers such as cellulose, hemicellulose, starch to VFA, $\mathrm{CO}_{2}, \mathrm{CH}_{4^{\prime}}$ and $\mathrm{H}_{2}$ (Mitsumori \& Sun, 2008) and the end products of microbial fermentation of amino acids, which are ammonia, volatile fatty acids, $\mathrm{CO}_{2}$, and $\mathrm{CH}_{4}$ (Pashaei et al., 2010). The greater of the organic materials used by rumen microbes, the higher the gas produced. There are some evidences suggesting the low level of SHW degradation in the rumen. The first is the high lignin content of SHW that reaches 17.53\% (Kisworo et al., 2016). According to Moreira et al. (2013), ligations between polysaccharides and lignin should favor the formation of clusters that tend to preclude the attack of enzymes produced by ruminal microorganisms on the glycosidic bonds between sugar monomers that constitute biopolymers hemicellulose and cellulose. In addition, lignocellulosic bonding is not easily broken because lignin can not be digested by the rumen bacteria that do not have ligninase enzyme. Second, the content of plant secondary metabolites, mainly tannins may form bonds with SHW carbohydrates and protein that made them difficult to degrade and then escapes to the lower gastro-intestinal tract. Lower in vitro gas production due to the action of tannins have been previously reported in other studies; this is applied when tannins are present in forage plants (Jayanegara et al., 2013) and when tannins are extracted from their original sources and added into dietary substrates (Jayanegara et al., 2015).

The increase in gas production in SilSHW after PEG addition showed high biological activity of tannin as confirmed by the high tannin content observed in SilSHW. The metabolite may inhibit fermentation of feedstuffs because of its antimicrobial characteristics. Inhibition of rumen microbial growth reduces the ability to degrade the feed nutrients and leads to a lower gas production of SHW. Tannin is able to bind the protein and protect it from degradation by rumen microbes. According to Makkar et al. (2007), the presence of tannins can reduce gas production in in vitro fermentation system due to the interaction between tannin and feed components, especially protein and fiber that contribute to gas production. Similar results were found by Bueno et al. (2008), Pellikaan et al. (2011), and Tan et al. (2011). PEG is able to bind tannins present in the SHW and then release proteins in solid herbal waste and can further be degraded by rumen microbes; this causes an increase in gas production of SHW silage after PEG addition. According to Jayanegara et al. (2009), polyethylene glycol (PEG) is a chemical that has a high affinity for tannins; tannins bind PEG to become unable to react with nutrients. Thus, an increase in gas production with the addition of PEG is a measure of the activity of tannins in forage plant.

With regard to gas production kinetics, the sum of $a$ and $b$ fractions $(a+b)$ can be interpreted as the maximum gas production during fermentation, while $c$ fraction is the rate of gas formation (Orskov \& McDonald, 1979). The three forms of solid herbal waste almost have the same nutrient contents, but the contents of plant secondary metabolites were different in which SHW silage was generally higher. Therefore the maximum gas production decline in SilSHW is supposedly influenced by the high content of plant secondary metabolites, particularly tannins. The lower gas production rate (c fraction) of SDSHW than FDSHW and SilSHW is presumably because the crude fiber content of SDSHW was slightly higher than FDSHW and SilSHW. This result was in agreement with finding of Nasser et al. (2009). Orskov \& Ryle (1990) stated that the $c$ fraction will be lower in feed containing high cellulose; feed with a low crude fiber will be easy to be digested and requires a shorter time per unit weight. PEG addition at all three forms of SHW is likely to increase the gas production rate although statistically it is not significant. The insignificant changes may suggest that $c$ fraction is more influenced by crude 
fiber content as compared to the levels of tannins in SHW.

The low production of methane from SHW compared to standard can be caused by high levels of tannins in solid waste. Such decrease of methane emissions due to tannins was also observed in other experiments (Jayanegara et al., 2013; 2015; Gemeda \& Hassen, 2015). According to Patra \& Saxena (2010), tannins decrease methanogenesis by directly reducing the number of protozoa and methanogenic archaea, and indirectly by reducing the degradation of crude fiber, which depends on the chemical structure of tannin and the methanogenic species. PEG addition did not significantly change methane concentration in both air-dried, freeze dry, or silage of SHW $(\mathrm{P}>0.05)$; this raises the suspicion of other secondary metabolites apart from tannins to cause a methane decrease. According to Jayanegara et al. (2009), the gas production increase with the addition of PEG indicates that the tannins decrease methane production in vitro conditions, the reversal of the methane production that is not full (incomplete reversal) by PEG addition, possibly due to the presence of other secondary metabolites in plants that are observed. In this research, it is known that solid waste herbs contain some secondary metabolites such as phenols, tannins, saponins, flavonoids, and alkaloids.

Saponins may decrease methane production via defaunation and/or directly by decreasing the activities (i.e. rate of methanogenesis or expression of methaneproducing genes) and numbers of methanogens (Patra \& Saxena, 2009), which are responsible for a considerable proportion of the total $\mathrm{CH}_{4}$ produced. Saponins have a potent antiprotozoal activity by forming complex with sterols in protozoal cell membranes (Goel \& Makkar, 2012). Research conducted by Herdian et al. (2011) demonstrates the leaves of Morinda citrifolia (pace) as a source of saponins have the ability to reduce the population of protozoa, reduce the production of methane, and increase the protein content of rumen microbes. Methane Mitigating Properties of Saponin-rich Sources in the ruminal methane emissions through a metaanalytical approach by Jayanegara et al. (2014) showed that an addition of increasing levels of a saponin-rich source decreased methane emission per unit of substrate incubated as well as per unit of total gas produced $(\mathrm{P}<0.05)$, and can be concluded that methane mitigating properties of saponins in the rumen are level- and source-dependent. Some evidences show that natural compounds of flavonoids also have direct effects against methanogens and to be an alternative agent to suppress methane production and improve animal health and productivity (Bodas et al., 2012). Oskoueian et al. (2013) demonstrated that flavonoids naringin and quercetin at the concentration of $4.5 \%$ of the substrate (dry matter basis) were potential metabolites to suppress methane production without any negative effects on rumen microbial fermentation. Seradj et al. (2014) found that relative quantification of the abundance of hydrogenotrophic methanogenic archaea (HMA) population was reduced by the addition of Bioflavex ${ }^{\circledR}$ and its pure flavonoid components (Narangine and Neohesperidine). Concentration the acetoclastic methanogenic archaea
Methanosarcina spp. was also inhibited by poncirine, neohesperidine, narangine, and Bioflave ${ }^{\circledR}$. Considering that the main proportion of methane synthesized in the rumen environment comes from the activity of HMA population.

Recent study on the role of alkaloids in rumen fermentation suggests alkaloids can reduce methane emissions and gas production. Research by Pereira et al. (2017) on the role of alkaloids extract from mesquite pods in rumen fermentation indicates natural alkaloids extract has similar potential to sodium monensin in reducing the production of total gases, methane, and the acetate/propionate ratio. Similar results were described by Santos et al. (2013) who observed that both monensin and the alkaloid-enriched extracts from Prosopis juliflora (Fabaceae) pods reduced gas production in vitro as compared with control, inferring that the alkaloids extracted from $P$. juliflora pods might have mitigated $\mathrm{CH}_{4}$ production by selectively destabilizing the relationships between the microbial and methanogenic communities and fibrolytic bacteria.

The results showed the lowest SilSHW $\mathrm{CH}_{4}$ level compared to SDSHW and FDSHW. This result differs from the grass silage that produces lower methane compared to its fresh form (Navarro-Villa et al., 2013) or the same as hay (Ribeiro et al., 2014) which is presumably due to the higher content of secondary metabolites of SilSHW compared to SDSHW and FDSHW.

The process of fermentation in the rumen, microbes hydrolyze a high proportion of dietary protein to amino acids which are then degraded to organic acids, ammonia, and $\mathrm{CO}_{2}$ (Kellems \& Church, 2010). Ammonia, a major source of nitrogen is very important for rumen microbial protein synthesis. The ammonia concentration in the rumen is a balance between the amount produced, the amount used by microbes and absorbed by the rumen wall. The ammonia that was produced from in vitro rumen fermentation of solid herbal waste was high enough ranged from 136 to $203 \mathrm{mg} / \mathrm{L}$ equivalent to 13.6 to $20.3 \mathrm{mg} / 100 \mathrm{~mL}$. According to Chantakhoun et al. (2012), $\mathrm{NH}_{3}$ production in the rumen ranges from 12.2 to $13.2 \mathrm{mg} / 100 \mathrm{~mL}$. The high production of $\mathrm{NH}_{3}$ allegedly due to in vitro fermentation system that causes ammonia to accumulate, because they can not be recycled as in the actual rumen conditions. Ammonia production from solid herbal waste was lower than pangola grass that used as standard in this research, although the crude protein levels were not much different. It is presumably because protein binds with tannins, in addition, SHW proteins content have been partially denatured or coagulated so as not to be digested by rumen microbes. Kellem \& Church (2010) stated that heating process results in an improvement in protein quality, partly by degrading anti-quality factors that were present. Heating also will reduce solubility of the protein, resulting in less degradation of protein in the rumen and shifting the digestion in the small intestinum. The low content of SHW ammonia than standard also caused by its use for microbial protein synthesis; this is indicated by the higher number of SHW microbial protein than standard pangola grass. Insignificant $\mathrm{NH}_{3}$ production among treatments allegedly caused by the indifferent 
protein content between SDSHW, FDSHW and SilSHW. In SHW silage, the low production of ammonia after the addition of PEG probably because some ammonia have been used for the formation of microbial protein with a soluble carbohydrate derived from the addition of molasses as a source of energy. This led to the higher production of SilSHW microbial protein than sun dried and freeze dried SHW.

The in vitro dry matter degradability (IVDMD) and organic matter degradability (IVOMD) of FDSHW were higher than SDSHW and SilSHW. This is partly due to the freeze drying process allegedly able to minimize the damage of nutrients in feed ingredients and allow more nutrients available to be digested by rumen microbes. This result is in agreement with the result of Oni et al. (2015) that found air dried and freeze dried vegetables maintained their protein, fat, fibre, ash, and carbohydrate contents when compared to those were oven dried and sun dried. The results obtained could be due to the fact that all this proximate components are actually affected by heat. According to Danso-Boateng (2013), heating caused the denaturation of protein cells, in turn weakening the three-dimensional conformation of the pro-tein cells, ultimately leading to protein loss. The IVDMD and IVOMD of SilSHW with and without PEG were lowest compared to sun dry and freeze dry SHW, except IVDMD and IVOMD of freeze dry SHW with PEG addition which was lower than SHW silage. This is presumably due to the higher levels of plant secondary metabolites in SilSHW compared to SDSHW and FDSHW. Plant secondary metabolites could inhibit rumen microbial growth thus reducing the ability to digest the plant cells due to inhibitory effect on fibrolytic and proteolytic bacteria, and reduced digestive enzymes activity. Plant secondary metabolites also protect nutrients from rumen digestion, for examples, tannins have the capacity to form complexes mainly with proteins via hydrogen bonds due to the presence of large number of phenolic hydroxyl groups and reducing protein degradation in rumen (Patra et al., 2012). In vitro degradability values of solid herbal waste in this study are equivalent to the degradability of rice straw but higher than pod husk cacao. According to Mahfuz et al. (2014), the value of dry matter and organic matter degradability of rice straw with $0-12 \mathrm{~g} / \mathrm{kg}$ phosphorous supplementations at $48 \mathrm{~h}$ was between $28.75 \%-56.25 \%$ and $35.77 \%-59.21 \%$ repectively, while dry matter degradability of fermented pod husk was between $21.75 \%-25.78 \%$ (Nelson, 2011), meanwhile in vitro digestibility of pod husks between $33.78 \%$ to $39.10 \%$ (Islamiyati, 2010).

\section{CONCLUSION}

All three preparations of SHW still contained sufficient nutrient to resemble fibrous feed materials, but also contained a variety of plant secondary metabolites. Gas production, methane, $\mathrm{NH}_{3}$, microbial protein and digestibility of SHW silage were the lowest as compared to those of sun dried and freeze dried SHW, apparently due to the high content of secondary metabolites especially tannin. It can be concluded that dried and silage of
SHW can be used as an alternative feed ingredients for ruminants.

\section{ACKNOWLEDGEMENT}

This work is supported by Animal Nutrition Department, Faculty of Animal Science UGM and Beasiswa S3 Kementerian Pertanian RI 2013. Authors would like to express deepest gratitude to PT. Deltomed Laboratories Tbk, Wonogiri, Jawa Tengah for providing solid herbal waste samples for this study.

\section{REFERENCES}

Al-Dobaib, S. N. 2009. Effect of different levels of quebracho tannin on nitrogen utilization and growth performance of Nadji sheep feed alfafa (Medicago sativa) hay as a sole diet. J. Anim. Sci. 80: 532-541. https://doi. org/10.1111/j.1740-0929.2009.00662.x

Amir, A. N. \& P. F. Lestari. 2013. Pengambilan oleoresin dari limbah ampas jahe industri jamu (PT. Sido Muncul) dengan metode ekstraksi. J. Teknologi Kimia dan Industri. 2: 88-95.

AOAC. 2005. Official Methods of Analysis of AOAC International. 18th ed. Assoc. Off. Anal. Chem., Arlington.

Blummel, M., H. Steingass, \& K. Becker. 1997. The relationship between in vitro gas production, in vitro microbial biomass yield and $15 \mathrm{~N}$ incorporation and its implications for the prediction of voluntary feed intake of rhougages. Br. J. Nutr. 77: 911-921. https://doi.org/10.1079/BJN19970089

Bodas, R., N. Prieto, R. Garcia-Gonzalez, S. Andres, F. J. Giraldez, \& S. Lopez. 2012. "Manipulation of rumen fermentation and methane production with plant secondary metabolites," Anim. Feed Sci. and Technol. 176: 78-93. https://doi.org/10.1016/j.anifeedsci.2012.07.010

Broderick G. A. \& J. H. Kang. 1980. Automated simultaneous determination of jammonia and total amino acids in ruminal fluid and in vitro media. J. Dairy Sci. 63: 64-75.

Bueno, I. C. S., D. M. S. S. Vitti, H. Louvandini, \& A. L. Abdalla. 2008. A new approach for in vitro bioassay to measure tannin biological effects based on a gas production technique. Anim. Feed Sci. and Technol. 141: 153-170. https://doi.org/10.1016/j.anifeedsci.2007.04.011

Chanthakhoun, V., M. Wanapat, P. Kongmun, \& A. Cherdthong. 2012. Comparison of ruminal fermentation characteristics and microbial population in swamp buffalo and cattle. Livestock Science 143: 172-176. https://doi. org/10.1016/j.livsci.2011.09.009

Chanwitheesuk, A., A. Teerawutgulrag, \& N. Rakariyatham. 2005. Screening of antioxidant activity and antioxidantcompounds of some edible plants of Thailand. Food Chemistry. 92: 491-497. https://doi.org/10.1016/j. foodchem.2004.07.035

Danso-Boateng, E. 2013. Effect of drying methods on nutrient quality of Basil (Ocimum viride) leaves cultivated in Ghana. Int. Food Res. J. 20: 1569-1573.

Dordevic', T. M., S. S. Šiler-Marinkovic', \& S. I. Dimitrijevic' Brankovic'. 2010. Effect of fermentation on antioxidant properties of some cereals and pseudo cereals. Food Chemistry. 119: 957-963. https://doi.org/10.1016/j. foodchem.2009.07.049

Gemeda, B. S. \& A. Hassen. 2015. Effect of tannin and species variation on in vitro digestibility, gas, and methane production of tropical browse plants. Asian-Australas. J. Anim. Sci. 28: 188-199. https://doi.org/10.5713/ajas.14.0325

Goel, G. \& H. P. S. Makkar. 2012. Methane mitigation from ruminants using tannins and saponins. Trop. Anim. Health Prod. 4: 729-739. https://doi.org/10.1007/s11250-011-9966-2 
Hartadi, H., S. Reksohadiprodjo, \& A. D. Tillman. 2005. Tables of Feed Composition for Indonesia. Gadjah Mada University Press, Yogyakarta.

Herdian, H., L. Istiqomah, A. Febrisiantosa, \& D. Setiabudi. 2011. Effect of addition of Morinda citrifolia leaf as saponin source on fermentation characteristics, protozoa defaunization, gas production and methane rumen fluids in vitro. (Article in Indonesian). JITV. 16: 98-103.

Islamiyati. 2010. In vitro dry matter digestibility of cocoa pods immersed in different alkaline solution. (Article in Indonesian). JITP. 1(1): 43-47.

Jayanegara, A. \& A. Sofyan. 2008. Determination of some forage tannery activity in vitro using 'Hohenheim Gas Test' with polyethylene glycol as a determinant. (Article in Indonesian). Med. Pet. 31: 44-52.

Jayanegara, A., A. Sofyan, H. P. S. Makkar, \& K. Becker. 2009. Gas production kinetics, organic matter digestibility and methane production in vitro in hay and straw diets supplemented by tannin-containing forages. Med. Pet. 32: 120-129.

Jayanegara, A., E. Wina, \& J. Takahashi. 2014. Meta-analysis on methane mitigating properties of saponin-rich sources in the rumen: influence of addition levels and plant sources. Asian-Australas. J. Anim. Sci. 27: 1426-1435. https://doi. org/10.5713/ajas.2014.14086

Jayanegara, A., S. Marquardt, E. Wina, M. Kreuzer, \& F. Leiber. 2013. In vitro indications for favourable non-additive effects on ruminal methane mitigation between highphenolic and high-quality forages. Br. J. Nutr. 109: 615-622. https://doi.org/10.1017/S0007114512001742

Jayanegara, A., G. Goel, H. P. S. Makkar, \& K. Becker. 2015. Divergence between purified hydrolysable and condensed tannin effects on methane emission, rumen fermentation and microbial population in vitro. Anim. Feed Sci. Technol. 209: 60-68. https://doi.org/10.1016/j.anifeedsci.2015.08.002

Kamra, D. N., M. Pawar, \& B. Singh. 2012. Effect of Plant Secondary Metaboliet on Rumen Methanogens and Methane Emisions By Ruminants. In.: Patra, A.K. Dietary Phytochemicals and Microbes. Spinger Dordrecht Heidelberg, New York London. p. 351-370. https://doi. org/10.1007/978-94-007-3926-0_12

Kellems, R. O. \& D. C. Church. 2010. Livestock Feeds and Feeding. 6th ed. Prentice Hall, New York.

Kisworo, A. N., A. Agus, Kustantinah, \& B. Suwignyo. 2016. Physicochemical characteristics identification and secondary metabolite analysis of solid herbal waste as source of feed rich fiber and supplement for ruminants. Animal Production. 18: 75-84. https://doi.org/10.20884/1. anprod.2016.18.2.535

Landete, J. M., J. A. Curiel, H. Rodri'guez, B. de las Rivas, \& R. Muñoz. 2008. Study of the inhibitory activity of phenolic compounds found in olive products and their degradation by Lactobacillus plantarum strains. Food Chem. 107: 320 326. https://doi.org/10.1016/j.foodchem.2007.08.043

Liu, L., R. Zhang, Y. Deng, Y. Zhang, J. Xiao, F. Huang, W. Wen, \& M. Zhang. 2017. Fermentation and complex enzyme hydrolysis enhance total phenolics and antioxidant activity of aqueous solution from rice bran pretreated by steaming with a-amylase. Food Chem. 221: 636-643. https://doi. org/10.1016/j.foodchem.2016.11.126

Mahfuz, S. U., M. R. Chowdhury, M.M. H. Khanc, \& M. A. Baset. 2014. Effect of triple super phosphate supplementation on degradability of rice straw and ammonia nitrogen concentration. Small Ruminant Res. 120: 15-19. https://doi. org/10.1016/j.smallrumres.2014.04.003

Makkar, H. P. S., G. Francis \& K. Becker. 2007. Bioactivity of phytochemicals in some lesserknown plants and their effects and potential applications in livestock and aquaculture production systems. Animal 1: 1371-1391. https://doi.
org/10.1017/S1751731107000298

Makkar, H. P. S., M. Bluemmel, N. K. Borowy, \& K. Becker. 1993. Gravimetric determination of tannins and their correlation with chemical and protein precipitation methods. J. Sci. Food Agric. 61: 161-165. https://doi.org/10.1002/ jsfa.2740610205

Makkar, H. P. S., O. P. Sharma, R. K. Dawra, \& S. S. Negi. 1982. Simple determination of microbial protein in rumen liquor. J. Dairy Sci. 65: 2170-2173. https://doi.org/10.3168/ jds.S0022-0302(82)82477-6

Manyawu, G., I. Chakoma, K. Gwezuva, L. Gwiriri, \& S. Moyo. 2016. Principles of silage making in the subtropics. ILRI extension brief. Nairobi, Kenya.

Martins, S., S. I. Mussatto, M. G. Avila, M. J. Saenz, C. N. Aguilar, \& J. A. Teixeira. 2011. Bioactive phenolic compounds: Production and extraction by solid-state fermentation. A review. Biotechnol. Adv. 29: 365-373. https://doi. org/10.1016/j.biotechadv.2011.01.008

Menke, K. H., L. Raab, A. Salewski, H. Steingass, D. Fritz, \& W. Schneider. 1979. The estimation of the digestibility and metabolizable energy content of ruminant feedingstuffs from the gas production when they are incubated with rumen liquor in vitro. The Journal of Agricultural Science. 93: 217-222. https://doi.org/10.1017/S0021859600086305

Menke, K.H. \& H. Steingass. 1988. Estimation of the energetic feed value obtained from chemical analysis and in vitro gas production using rumen fluid. Anim. Res. Dev. 28: $7-55$.

Ministry of Health. 1995. Materia Medika Indonesia Jilid VI. Departemen Kesehatan Republik Indonesia.

Ministry of Health. 2008. Farmakope Herbal Indonesia Edisi I. Departemen Kesehatan Republik Indonesia.

Mitsumori, M. \& W. Sun. 2008. Control of rumen microbial fermentation for mitigating methane emissions from the rumen. Asian-Australas. J. Anim. Sci. 21: 144-154. https:// doi.org/10.5713/ajas.2008.r01

Moreira, L. M., F. P. Leonel, R. A. M. Vieira, \& J. C. Pereira. 2013. A new approach about the digestion of fibers by ruminants. Rev. Bras. Saúde Prod. Anim. 14: 382-395.

Nasser, M. E. A., A. M. El Waziry, \& S. M. A. Sallam. 2009. In Vitro Gas Production Measurements and Estimated Energy Value and Microbial Protein to Investigate Associative Effects of Untreated or Biological Treated Linen Straw and Berseem Hay. In: Papach ristou, T.G. (ed.), Z.M. Parissi (ed.), H. Ben Salem (ed.), \& P. Morand-Fehr (ed.). Nutritional and Foraging Ecology of Sheep and Goats. Zaragoza: CIHEAM / FAO / NAGREF. p. 61-266 (Options Méditerranéennes : Série A. Séminaires. Méditerranéens; n. 85)

Navarro-Villa, A., M. O'Brien, S. López, T. M. Boland, \& P. O'Kiely. 2013. In vitro rumen methane output of grasses and grass silages differing in fermentation characteristics using the gas-production technique. Grass Forage Sci. 68: 228-244. https://doi.org/10.1111/j.1365-2494.2012.00894.x

Nazarni, R., D. Purnama, S. Umar, \& H. Eni. 2016. The effect of fermentation on total phenolic, flavonoid and tannin content and its relation to antibacterial activity in jaruk tigarun (Crataeva nurvala, Buch HAM). IFRJ. 23: 309-315.

Nelson. 2011. Degradasi bahan kering dan produksi asam lemak terbang in vitro pada kulit buah kakao terfermentasi. Jurnal Ilmiah Ilmu-Ilmu Peternakan. 14: 44-50. https://online journal.unja.ac.id/index.php/jiip/article/view/587/531.

Nurjana, D. J., S. Suharti, \& Suryahadi. 2016. Improvement of napier grass silage nutritive value by using inoculant and crude enzymes from Trichoderma reesei and its effect on in vitro rumen fermentation. Med. Pet. 39: 46-52. https:// doi.org/10.5398/medpet.2016.39.1.46

Oni, M. O., O. C. Ogungbite, \& A. K. Akindele. 2015. The effect of different drying methods on some common Nigerian 
edible botanicals. IJARB. 1: 15-22.

Orskov \& M. Ryle. 1990. Energy Nutrition in Ruminants. Elsevier Scince Publisher.

Orskov, E. R. \& McDonald. 1979. The estimation of protein degradability in the rumen from incubation measurements weighted according to rate of passage. J. Agric. Sci. Cambridge. 92: 499-503. https://doi.org/10.1017/ S0021859600063048

Oskoueian, E., N. Abdullah, \& A. Oskoueian. 2013. Effects of flavonoids on rumen fermentation activity, methane production, and microbial population. BioMed Research International Volume 2013: 1-8. https://doi. org/10.1155/2013/349129

Osman, M. A. 2011. Effect of traditional fermentation process on the nutrient and antinutrient contents of pearl millet during preparation of Lohoh. Journal of the Saudi Society of Agric. Sci. 10: 1-6.

Othman, N. B., D. Roblain, N. Chammen, P. Thonart, \& M. Hamdi. 2009. Antioxidant phenolic compounds loss during the fermentation of Chetoui olives. Food Chem. 116: 662-669. https://doi.org/10.1016/j.foodchem.2009.02.084

Pashaei, S., V. Razmazar, \& R. Mirshekar. 2010. Gas production: a proposed in vitro method to estimate the extent of digestion of a feedstuff in the rumen. Journal of Biological Sciences. 10: 573-580. https://doi.org/10.3923/ jbs.2010.573.580

Patra, A. K. \& J. Saxena. 2009. The effect and mode of action of saponins on the microbial populations and fermentation in the rumen and ruminant production. Nutrition Research Reviews. 22: 204-219. https://doi.org/10.1017/ S0954422409990163

Patra, A. K. \& J. Saxena. 2010. A new perspective on the use of plant secondary metabolites to inhibit methanogenesis in the rumen. Phytochemistry. 71: 1198 -1222. https://doi. org/10.1016/j.phytochem.2010.05.010

Patra, A.K., B-R. Min, \& J. Saxena. 2012. Dietary Tannin on Microbial Ecology of the Gastrointestinal Tract in Ruminants. In: Patra, A.K.(Ed). Dietary Phytochemicals and Microbes. p. 237-262. Spinger Dordrecht Heidelberg, New York, London. https://doi.org/10.1007/978-94-007-3926-0_8

Pellikaan,W. F., E. Stringano, J. Leenaars, D. J. G. M. Bongers, S. L. Schuppen, J. Plant, \& I. Mueller-Harvey. 2011. Evaluating effects of tannins on extent and rate of in vitro gas and $\mathrm{CH} 4$ production using an automated pressure evaluation system (APES). Anim. Feed Sci. Technol. 166-167: 377-390. https://doi.org/10.1016/j.anifeedsci.2011.04.072

Pereira, T. C. J., M. L. A. Pereira, J. V. Moreira, J. a. G. Azevedo, R. Batista, V. F. Paula, B. S. Oliveira, \& E. J. Santos. 2017. Effects of alkaloid extracts of mesquite pod on the products of in vitro rumen fermentation. Environ. Sci. Pollut. Res. 24:4301-431. https://doi.org/10.1007/s11356-016-7761-3
Plummer, D.T. 1987. An introduction to Practical Biochemistry. 3rd edition. pp. 332. McGraw-Hill (UK).

Ribeiro, Jr., G.O., A. M. Teixeira, F. O. Velasco, W. G. Faria Júnior, L. G. R. Pereira, A. V. Chaves, L. C. Gonçalves, \& T. A. McAllister. 2014. Production, nutritional quality and in vitro methane production from Andropogon gayanus grass harvested at different maturities and preserved as hay or silage. Asian-Australas. J Anim Sci. 27: 330-341. https://doi.org/10.5713/ajas.2013.13161

Rodríguez, H., J. A. Curiel, J. M. Landete, B. Rivas, F. L. Felipe, C. Gómez-Cordovés, J. M. Manche-o, \& R. Mu-oz. 2009. Food phenolics and lactic acid bacteria. International Journal of Food Microbiology. 132: 79-90. https://doi. org/10.1016/j.ijfoodmicro.2009.03.025

Santos, E. T., M. L. A. Pereira, C. F. P. G. Silva, L. C. Souza-Neta, R. Geris, D. Martins, A. E. G. Santana, L. A. Barbosa, H. G. O. Silva, G. C. Freitas, M. P. Figueiredo, F. F. Oliveira \& R. Batista. 2013. Antibacterial activity of the alkaloidenriched extract from Prosopis juliflora pods and its influence on in vitro ruminal digestion. Int. J. Mol. Sci. 14: 84968516. https://doi.org/10.3390/ijms14048496

Seradj, A.R., L. Abecia, J. Crespo, D. Villalba, M. Fondevila, \& J. Balcells. 2014. The effect of Bioflavex ${ }^{\circledR}$ and its pure flavonoid components on in vitro fermentation parameters and methane production in rumen fluid from steers given high concentrate diets. Anim. Feed Sci. Technol. 197:85-91. https://doi.org/10.1016/j.anifeedsci.2014.08.013

Stahl, E. 1985. Analisis Obat secara Kromatografi dan Mikroskopi. Penerjemah: Padmawinata, K. dan I. Sudiro. Penerbit ITB, Bandung.

Tan, H. Y., C. C. Sieo, N. Abdullah, J. B. Liang, X. D. Huang, \& Y.W. Ho. 2011. Effects of condensed tannins from Leucaena on methane production, rumen fermentation and populations of methanogens and protozoa in vitro. Anim. Feed Sci. Technol. 169: 185-193. https://doi.org/10.1016/j. anifeedsci.2011.07.004

Utomo, R. 2016. Konservasi Hijauan Pakan dan Peningkatan Kualitas Bahan Pakan Berserat Tinggi. Gadjah Mada University Press, Yogyakarta.

Utomo, R., M. Soejonoa, B. P. Widyobroto, \& Sudirman. 2011. Determination of in vitro digestibility of tropical feeds using cattle faeces as rumen fluid alternative. Med. Pet. 34: 207-211. https://doi.org/10.5398/medpet.2011.34.3.207

Valli, V., A. M. Gómez-Caravaca, M. D. Nunzio, F. Danesi, M. F. Caboni, \& A. Bordoni. 2012. Sugar cane and sugar beet molasses, antioxidant-rich alternatives to refined sugar. J. Agric. Food Chem. 60: 12508-12515.

Wink, M. 2015. Modes of action of herbal medicines and plant secondary metabolites, a review. Medicines. 2: 251-286. https://doi.org/10.3390/medicines2030251 